\title{
URGENSI TES URIN BAGI PASANGAN CALON PENGANTIN PERSPEKTIF ISTIHSAN AL-SYARAKHSY
}

\author{
Hawa' Hidayatul Hikmiyah \\ Universitas Islam Negeri Maulana Malik Ibrahim Malang \\ Email: hawahidayatulhikmiyah@gmail.com
}

Aspandi

Institut Pesantren KH. Abdul Chalim Mojokerto

Email: aspandimukardi@gmail.com

\begin{abstract}
In carrying out marriage there are harmony and conditions that must be met, includes the existence of a prospective husband, prospective wife, marriage guardian, two witnesses, and qobul consent, the provision is based on KHI article 14 in chapter IV concerning the terms of marriage. But in 2019, the East Java region imposed a urine test on the bride and groom as additional marriage conditional. Urine test conducted for the bride and groom is a policy of the regional office of the ministry of religion in East Java in an effort to reduce the number of drug abuse. Because the number of drug users in East Java is very high and has expanded to remote areas of the village so that prevention and control effort are needed evenly, efficiently and structured. With the enactment of the policy of the regional office of the ministry of religion in East Java above, the religious affairs office obliges the bride and groom to take a medical and urine test. Implementation of this urine test will not obstruct the marriage process of the bride and groom, if one or both brides are proven to use narcotics, the bride and groom will get rehabilitation treatment by the East Java BNNP. This is done so that the condition in question does not become worse after marriage. Using the analysis of Istihsan al Syarakhsy shows that there is harmony and as a reinforcement that the urgency of urine tests for brides is a form of response both done in an effort to get justice and benefit.
\end{abstract}

Key word : Urine Test, candidate of bride and groom, Istihsan Al-Sirakhsy

\begin{abstract}
ABSTRAK
Dalam melaksanakan pernikahan terdapat rukun dan syarat yang harus dipenuhi, meliputi adanya calon suami, calon istri, wali nikah, dua orang saksi dan ijab Kabul, ketentuan tersebut berdasarkan KHI pasal 14 pada Bab IV tentang rukun dan syarat perkawinan. Akan tetapi pada tahun 2019, wilayah Jawa Timur memberlakukan tes urin bagi calon pengantin sebagai tambahan syarat pernikahan. Tes urin yang dilakukan bagi pasangan calon pengantin merupakan langkah kebijakan kanwil kemenag jatim dalam upaya menurunkan angka penyalahgunaan narkoba. Karna angka pemakai narkoba di wilayah Jawa Timur sangat tinggi dan telah meluas sampai wilayah pelosok pedesaan sehingga perlu dilakukan upaya pencegahan dan penanggulangan secara merata, efisien dan terstruktur. Dengan adanya pemberlakuan kebijakan kanwil kemenag Jatim diatas, maka pihak Kantor Urusan Agama (KUA) mewajibkan calon pengantin untuk melakukan tes kesehatan serta tes urin. Pelaksanaan tes urin ini tidak akan menghalangi proses pernikahan calon pasangan pengantin. Jika salah satu atau kedua pengantin terbukti menggunakan narkotika, maka calon pengantin akan mendapatkan penanganan rehabilitasi oleh BNNP Jatim. Hal ini dilakukan agar kondisi yang bersangkutan tidak menjadi lebih parah setelah menikah nanti. Memakai analisis istihsan al-syarakhsy menunjukkan adanya keselarasan serta sebagai penguatan bahwa urgensi tes urin bagi calon pengantin merupakan sebuah bentuk penganggapan baik dilakukan dalam upaya mendapatkan keadilan dan kemaslahatan.
\end{abstract}

Kata Kunci: Tes Urin, Calon Pengantin, Istihsan Al-Syarakhsy 


\section{PENDAHULUAN}

Perkawinan menurut hukum Islam adalah pernikahan, hal ini jelas termaktub dalam Kompilasi Hukum Islam (KHI) yang menyatakan bahwa suatu pernikahan merupakan sebuah akad yang sangat kuat atau mitsaqan ghalidzan untuk mentaati perintah Allah dan melaksanakannya merupakan ibadah yang bertujuan untuk mewujudkan kehidupan rumah tangga yang sakinah, mawaddah, dan rahmah. ${ }^{1}$ Dalam pernikahan pun mempunyai syarat-syarat dan rukun yang harus dipenuhi meliputi calon suami, calon istri, wali nikah, dua orang saksi, dan ijab Kabul.

Dalam Islam pun telah menetapkan syarat dan rukun yang harus dipenuhi dalam perkawinan untuk tercapainya perkawinan yang sah sesuai syara'. Tidak cukup itu, di Indonesia supaya perkawinan itu sah di mata negara, maka perkawinan itu harus dilangsungkan sesuai dengan ketentuan undang-undang, yaitu UU No. 1 Tahun 1974 tentang Perkawinan dan KHI yang merupakan pengembangan hukum perkawinan yang tertuang dalam UU No. 1 Tahun 1974. Oleh karena itu,ia tidak lepas dari misi yang diemban UU Perkawinan tersebut, kendatipun cakupannya hanya terbatas untuk orang Islam. ${ }^{2}$ Seperti adanya calon pengantin laki-laki dan perempuan dalam perkawinan.5 Sedangkan syarat adalah sesuatu yang menentukan sah atau tidaknya suatu pekerjaan (ibadah), tetapi sesuatu itu tidak termasuk dalam rangkaian pekerjaan itu, seperti menurut Islam, calon pengantin laki-laki dan perempuan harus beragama Islam.6 Sedangkan syarat dalam perkawinan adalah sesuatu yang harus ada dalam perkawinan tetapi tidak termasuk hakikat dari perkawinan itu. Apabila salah satu syarat perkawinan itu tidak terpenuhi, maka perkawinan tersebut tidak sah. ${ }^{3}$ Rukun dan syarat perkawinan itu menentukan sah atau tidaknya sebuah perkawinan, sehingga rukun dan syarat tersebut merupakan suatu kewajiban yang harus dipenuhi bagi setiap pihak yang hendak melangsungkan perkawinan.

Penentuan rukun dan syarat perkawinan dalam hukum Islam di kalangan ulama masih terdapat perbedaan pendapat. Namun, jumhur ulama berpendapat bahwa rukun perkawinan itu terdiri atas mempelai laki-laki dan mempelai perempuan yang hendak

\footnotetext{
${ }^{1}$ Kompilasi Hukum Islam (KHI) Cet. Terbaru: Permata Press, 2.

${ }^{2}$ Ahmad Rofiq, Hukum Islam di Indonesia, (Jakarta: Rajawali Press, Cet. II, 1997), 57.

${ }^{3}$ Wasman, Wardah Nuroniyah, Hukum Perkawinan Islam di Indonesia; Perbandingan Fiqh dan Hukum Positif, (Yogyakarta: Teras, Cet. 1, 2011), 30.
} 
melangsungkan perkawinan, wali dari pihak wanita, dua orang saksi dan sigat akad nikah (ijab kabul). ${ }^{4}$ Sedangkan syarat perkawinan itu adalah syarat yang bertalian dengan rukun-rukun perkawinan, yaitu syarat-syarat bagi calon mempelai laki-laki dan perempuan, wali, saksi, dan ijab kabul. ${ }^{5}$ Apabila syarat-syarat perkawinan tersebut terpenuhi, maka perkawinan it u sah dan timbullah hak dan kewajiban sebagai suami istri. Undang-Undang perkawinan hanya membicarakan syarat-syarat perkawinan, yang mana syarat-syarat tersebut lebih banyak berkenaan dengan unsur-unsur atau rukun perkawinan. Syarat-syarat tersebut tercantum dalam pasal 6 sampai pasal 12 UU No. 1 Tahun 1974, Syarat perkawinan yang tercantum dalam UU No. 1 Tahun 1974 tidak sama persis dengan syarat-syarat perkawinan dalam Islam, sebagaimana yang sudah dijelaskan oleh para ulama di kitab-kitab fikih. Syarat perkawinan dalam UU No. 1 Tahun 1974 dapat dikelompokkan menjadi dua, yaitu syarat intern dan syarat ekstern. Syarat intern merupakan syarat yang harus ada pada para pihak terutama mengenai kehendak, wewenang, dan persetujuan orang lain yang diperlukan para pihak dalam melaksanakan perkawinan. ${ }^{6}$ Sedangkan yang dimaksud dengan syarat ekstern adalah syarat yang berhubungan dengan cara atau formalitas pelangsungan perkawinan. ${ }^{7}$ Peraturanperaturan mengenai perkawinan yang sudah diatur dalam Undang-Undang Perkawinan dan Kompilasi Hukum Islam ternyata belumlah cukup untuk mengakomodir masalahmasalah perkawinan yang berkembang di masyarakat. Hal inilah yang menimbulkan munculnya kebijakan-kebijakan khusus sebagai upaya memecahkan problem yang terjadi dimasyarakat. Meskipun demikian, kebijakan tersebut tidaklah boleh bertentangan dengan peraturan pokok yang sudah ada (lex superior derogat lex inferior).

Islam sangat memperhatikan masalah kesehatan, baik kesehatan fisik, mental, dan kesehatan lingkungan. Hal ini dapat ditemukan di dalam Al-qur'an maupun Hadits yang merupakan sumber hukum Islam dan menjadi pedoman hidup bagi seluruh umat Islam. Bahkan dalam memilih pasangan hendaknya memilih pasangan yang subur. Dan jika diketahui bahwa ia seorang yang mandul, maka sebaiknya tidak menikahinya.

\footnotetext{
${ }^{4}$ Abd. Rahman Ghazaly, Fiqh Munakahat, (Jakarta: Kencana, Cet. II, 2006), 46-47.

${ }^{5}$ Sa'id bin Abdullah bin Thalib al Hamdani, Risalah al-Nikah, terjemahan, Agus Salim, Risalah Nikah; Hukum Perkawinan Islam, (Jakarta: Pustaka Amani, 2002), 67.

${ }^{6}$ A. Masjkur Anhari, Usaha-Usaha untuk Memberikan Kepastian Hukum dalam Perkawinan, (Surabaya: Diantama, 2007), 25.

${ }^{7}$ Ibid, 27.
} 
Apabila belum diketahui keadaannya karena belum pernah menikah, hendaknya mengamati kesehatan tubuhnya serta keremajaan usianya. Kedua sifat ini, pada umumnya merupakan indikasi kesuburan seorang wanita. Maka dari itu pasangan calon suami isteri dianjurkan untuk melakukan checkup kesehatan sebelum melangsungkan pernikahan. Laki-laki dan wanita yang hendak melangsungkan pernikahan menjalani diagnosis dan pemeriksaan untuk mengetahui kemungkinan mengidap berbagai penyakit keturunan, penyakit menular, masalah seksual dan kebiasaan-kebiasaan sehari-hari yang dapat berpengaruh di kemudian hari terhadap kesehatan calon suami isteri, atau anakanak mereka saat dilahirkan. ${ }^{8}$

Akan tetapi, pada tahun 2019 ini, Kantor Wilayah Kementrian Agama (Kanwil Kemenag) Jawa Timur mensyaratkan pasangan calon pengantin yang akan menikah untuk melakukan tes urin. Syarat tersebut akan dilaksanakan pada awal Agustus 2019. Dengan adanya kebijakan baru tentang keharusan tes urin, maka bertambah pula syaratsyarat yang harus dipenuhi oleh calon pengantin. Pelaksana tugas (PLt) kepala Kanwil Kemenag Jatim Moch Amin Mahfud mengatakan tes urin bagi calon pengantin dilakukan untuk mengantisipasi penggunaan narkoba di kalangan remaja, termasuk calon pengantin. Langkah ini juga dilakukan sebagai upaya menyelamatkan generasi muda dari jerat narkoba. ${ }^{9}$

Pada program ini merupakan kerjasama pihak Kanwil Kemenag Jawa Timur dengan Badan Narkotika Nasional Provinsi (BNNP) Jatim. Nantinya, pengantin diminta menyertakan hasil tes urin dalam berkas pengajuan pernikahan. Sebagai langkah awal syarat adanya tes urin bagi calon pasangan akan diberlakukan di 38 Kantor Urusan Agama (KUA). Hasil tes urine tidak akan menghalangi proses pernikahan jika suatu ketika salah satu calon pengantin terindikasi memakai narkotika. Justru, pengantin yang terindikasi sebagai pengguna narkotika akan mendapatkan penanganan rehabilitasi oleh BNNP Jatim.

Menurut data survey lembaga Ilmu pengetahuan Indonesia (LIPI) dan Puslatdin BNN, sedikitnya ada 7,5 \% pelajar di Jawa Timur terlibat penyalahgunaan narkoba.

\footnotetext{
${ }^{8}$ Abu Malik kamal bin Sayyid Salim, Fiqh Sunnah untuk Wanita, (Jakarta: Al- I'tishom Cahaya Umat, 2007), 648 .

9 https://m.cnnindonesia.com/nasional/20190713020347-20-411767/kua-di-jatim-bakal-wajibkan-calonpengantin-tes-urine diakses pada 05 November 2019.
} 
Sementara pada kalangan pekerja, sebanyak 2,80 \% dinyatakan positif narkoba. Dengan adanya kebijakan ini menjadi media pendidikan dan edukasi kepada para calon pengantin dan orang tua terkait bahayanya narkoba. pelaksanaan tes urin tersebut dilakukan secara gratis atau tanpa dipungut biaya sepeserpun melalui puskesmas atau kantor-kantor BNN di daerah masing-masing. ${ }^{10}$

Istihsan merupakan menganggap sesuatu itu baik. Pada hakikatnya istihsan bukanlah sumber hukum yang berdiri sendiri, karena dalil hukum dari bentuk istihsan pertama adalah qiyas yang tersembunyi yang diunggulkan dari pada yang nyata, sebab hal tertentu yang oleh mujtahid dianggap lebih unggul, dan itu adalah alasan istihsan. Sedangkan dalil hukum dari bentuk istihsan yang kedua adalah kemaslahatan, yang menuntut adanya perkecualian bagian tertentu dari hukum umum, dan hal itu juga dianggap sebagai alasan istihsan. Diantara orang-orang yang berhujjah dengan istihsan adalah mayoritas kelompok hanafi. Mereka beralasan: pengambilan dalil dengan qiyas yang samar yang mengalahkan qiyas yang nyata, atau memenangkan qiyas atas qiyas lain yang menentangnya karna kepentingan umum dengan cara mengecualikan sebagian dari hukum umum. Dan semua itu adalah pengambilan dalil yang benar. Pada hal ini memakai istihsan al-sharakhsy yang mengemukakan bahwa metode istihsan yakni menggunakan akal dalam menentukan mashlahat dan keadilan itu lebih baik diutamakan daripada menggunakan qiyas adalah pendapat madhabnya yang diyakini kuat dan benar. ${ }^{11}$

\section{TES URIN BAGI PASANGAN CALON PENGANTIN: URGENSI, LATAR BELAKANG DAN MANFAAT}

Narkotika merupakan zat yang tidak asing lagi. "Narkotika merupakan salah satu obat yang diperlukan dalam dunia pengobatan, demikian juga dalam bidang penelitian untuk tujuan pendidikan, pengembangan ilmu dan penerapannya". Narkotika secara umum yakni sejenis zat yang dapat menimbulkan pengaruh-pengaruh tertentu bagi orang-orang yang menggunakannya, yaitu dengan cara memasukkan kedalam tubuh. Penyalahgunaan narkotika menjadi masalah besar karena dapat pula menimbulkan

10 https://m.cnnindonesia.com/nasional/20190713020347-20-411767/kua-di-jatim-bakal-wajibkan-calonpengantin-tes-urine diakses pada 05 November 2019.

${ }^{11}$ Abdul Wahhab Khalaf, Ilmu ushul fikih- kaidah hukum Islam, terj. Faiz el muttaqin (Jakarta: pustaka amani, 2003), 104. 
ketergantungan yang berkepanjangan jika dipergunakan tidak sesuai dengan dosis dan pengawasan yang ketat. Penyalahgunaan narkotika juga mengakibatkan gangguan fisik, mental, sosial, keamanan dan ketertiban masyarakat.

Narkotika merupakan zat atau obat yang berasal dari tanaman atau bukan tanaman, baik sintetis maupun semisintetis, yang dapat menyebabkan penurunan atau perubahan kesadaran, hilangnya rasa, mengurangi sampai menghilangkan rasa nyeri, dan dapat menimbulkan ketergantungan, yang dibedakan ke dalam golongan-golongan sebagaimana terlampir dalam Undang-Undang narkotika. ${ }^{12}$ Zat-zat narkotika yang semula ditujukan untuk kepentingan pengobatan. Namun dengan perkembangan ilmu pengetahuan dan tekhnologi, khususnya perkembangan tekhnologi obat-obatan maka jenis-jenis narkotika dapat diolah sedemikian banyak seperti yang terdapat pada saat ini, serta dapat pula disalahgunakan fungsinya yang bukan lagi untuk kepentingan di bidang pengobatan, bahkan sudah mengancam kelangsungan eksistensi generasi suatu bangsa.

Penggunaan narkotika secara berkali-kali dapat membuat seseorang dalam keadaan tergantung pada narkotika. "Ketergantungan ini bisa ringan dan bisa berat. Berat ringannya ketergantungan ini diukur dengan kenyataan sampai beberapa jauh ia bisa melepaskan diri dari penggunaan itu. ${ }^{13}$ Upaya penanggulangan penyalahguaan narkotika telah banyak dilakukan, baik itu upaya preventif (pecegahan) seperti melakukan penyuluhan-penyuluhan mengenai dampak penyalahgunaan narkoba, baik yang dilakukan oleh Badan Narkotika Nasional (BNN) dan/atau aparat kepolisian dan upaya represif (penindakan) yaitu menindak mereka yang menyalahgunakan narkotika yang dilakukan oleh aparat kepolisian termasuk juga BNN yang bertindak sendirisendiri. Di Jawa Timur sudah dilakukan upaya penanggulangan penyalahgunaan narkotika, baik itu upaya preventif dan reperesif. Akantetapi para pengguna narkoba masih juga banyak.

Mengenai latar belakang kebijakan kanwil kemenag Jawa Timur yakni mengacu pada data survey lembaga Ilmu pengetahuan Indonesia (LIPI) dan Puslatdin BNN, sedikitnya ada 7,5\% pelajar di Jawa Timur terlibat penyalahgunaan narkoba. Sementara pada kalangan pekerja, sebanyak $2,80 \%$ dinyatakan positif narkoba. Dengan adanya

\footnotetext{
12 Taufik Makarao, dkk, Tindak Pidana Narkotika, (Jakarta: Ghalia Indonesia, 2003), 16.

${ }^{13}$ Andi Hamzah, Perkembangan Hukum Pidana Khusus, (Jakarta: Rineka Cipta, 1991), 176.
} 
kebijakan ini menjadi media pendidikan dan edukasi kepada para calon pengantin dan orang tua terkait bahayanya narkoba. pelaksanaan tes urin tersebut dilakukan secara gratis atau tanpa dipungut biaya sepeserpun melalui puskesmas atau kantor-kantor BNN di daerah masing-masing. ${ }^{14}$

Penyalahgunaan narkoba berbahaya bagi perkembangan sumber daya manusia dan mengancam kehidupan bangsa maupun Negara. Berbicara masalah bangsa dan Negara tidak luput dari peran lingkungan kecil dahulu yakni keluarga. Karena baik buruknya generasi berawal dari sebuah keluarga. Melihat angka penyalah gunaan narkoba di wilayah Jawa Timur sangat tinggi dan telah meluas diseluruh pelosok desa sehingga perlu dilakukan upaya pencegahan dan penanggulangan secara sistematis, terstruktur, efektif dan efisien. Dengan latar belakang permasalahan diatas maka kanwil kemenag membuat kebijakan adanya tes urin bagi pasangan calon pengantin. Tes urine merupakan tes pada spesimen yang paling sering digunakan untuk pemeriksaan narkoba rutin karena ketersediaannya dalam jumlah besar dan memiliki kadar obat dalam jumlah besar sehingga lebih mudah mendeteksi obat dibandingkan pada spesimen lain. Teknologi yang digunakan pada pemeriksaan narkoba pada urin sudah berkembang baik. Kelebihan lain spesimen urin adalah pengambilannya yang tidak invasif dan dapat dilakukan oleh petugas yang bukan medis. Urine merupakan matriks yang stabil dan dapat disimpan beku tanpa merusak integritasnya. Obat-obatan dalam urine biasanya dapat dideteksi sesudah 1-3 hari. Kelemahan pemeriksaan urine adalah mudahnya dilakukan pemalsuan dengan cara substitusi dengan bahan lain maupun diencerkan sehingga mengacaukan hasil pemeriksaan.

Pada umumnya, fungsi dari hasil tes urine yaitu sebagai salah satu faktor yang akan menetukan pasal apa yang akan dikenakan kepada tersangka yaitu apakah tersangka sebagai pemakai atau pemakai sekaligus pengedar atau hanya sebagai pengedar saja. Hasil dari tes urine saja tidak akan bisa menentukan apakah tersangka sebagai pemakai, pengedar atau kedua-duanya tanpa adanya faktor pendukung lainnya seperti jumlah barang bukti yang ditemukan dalam TKP dan keterangan-keterangan warga sekitar yang merupakan tetangga pelaku yang nantinya akan menjadi keterangan

\footnotetext{
${ }^{14}$ https://m.cnnindonesia.com/nasional/20190713020347-20-411767/kua-di-jatim-bakal-wajibkan-calonpengantin-tes-urine diakses pada 05 November 2019.
} 
saksi serta bukti-bukti lainnya. Oleh karena itu hasil tes urine ini hanya sebagai petunjuk yang gunanya nanti akan memperlihatkan apakah tersangka menggunakan narkotika atau tidak.

Kebijakan tersebut diharapkan dapat meminimalisir penyalahgunaan narkoba khususnya pada wilayah Jawa Timur. Berdasarkan peraturan daerah provinsi Jawa Timur Nomor 13 Tahun 2016 tentang Fasilitasi pencegahan dan penanggulangan penyalahgunaan narkoba dalam antisipasi dini dilakukan oleh pemerintah provinsi, artinya pemerintah provinsi memberikan informasi mengenai larangan dan bahaya narkoba serta dampak buruknya melalui berbagai kegiatan dan media informasi. Hal ini pemerintah provinsi bekerja sama dengan instansi vertical, perguruan tinggi dan/atau instansi lainnya untuk melakukan gerakan anti narkoba. Maka dari itu kanwil kemenag bekerjasama dengan pihak BNN agar memfasilitasi pemeriksaan penyalahgunaan narkoba bagi pasangan calon pengantin. Menurut Kanwil Kemenag Jatim, ia telah menandatangani MoU dengan Badan Narkotika Nasional Provinsi (BNNP) Jatim dalam mempersiapkan generasi emas sejak dini. Kerja sama yang ditandatangani Jumat, 12 Juli 2019 itu, salah satu pointnya ingin mewujudkan keluarga bebas narkoba melalui kebijakan tes urine bagi calon pengantin yang akan mengurus surat nikah ke Kantor Urusan Agama (KUA). ${ }^{15}$

Terkait dengan dijadikannya hasil tes urine sebagai persyaratan dalam perkawinan di beberapa wilayah Jawa Timur, maka setiap calon pengantin wajib melakukan tes urine tanpa terkecuali. Apabila calon pengantin tersebut tidak mau melakukan tes urine, maka konsekuensinya adalah PPN akan mempersulit proses pendaftaran dan pemeriksaan kedua calon mempelai. Secara substansi, ditetapkannya kebijakan tersebut adalah suatu hal yang positif, akan tetapi menjadikan tes urine tersebut sebagai persyaratan wajib dalam perkawinan, dirasa memberatkan calon pengantin karena adanya pembebanan lebih dari segi biaya administrasi jika calon pengantin tidak bersedia untuk melakukan tes urin di BNN terdekat dan proses pendaftaran perkawinan, yang mana syarat dan rukun nikah dalam Islam maupun undang-undang, kewajiban tes urine itu tidak syaratkan dalam sebuah perkawinan.

\footnotetext{
${ }^{15}$ https://surabaya.liputan6.com/read/4017888/calon-pengantin-di-surabaya-wajib-tes-urine-mulaiagustus-2019-mengapa diakses pada 06 November 2019.
} 


\section{ISTIHSAN AL-SYARAKHSY}

Menurut bahasa Istihsan adalah menganggap baik sesuatu. Menurut istilah ulama ushul adalah beralihnya pemikiran seseorang mujtahid dari tuntutan qiyas yang nyata kepada qiyas yang samara tau dari hukum umum kepada perkecualian karena ada kesalahan pemikiran yang kemudian memenangkan perpindahan itu. Apabila terjadi suatu peristiwa yang tidak terdapat nash hukumnya, maka dalam pembahasannya ada dua pendapat yang berbeda: sudut pandang lahiriyah yang menghendaki suatu hukum dari sudut pandang secara tersembunyi, lalu pindah dari sudut pandang lahiriyah. Inilah yang menurut syara' disebut istihsan. Demikian juga jika hukum itu bersifat umum, sedangkan dalam diri mujtahid ada dalil yang menuntut pengecualian atas sebagian hukum umum ini, lalu ia menghukumi perkecualian itu dengan hukum yang lain. maka ini juga disebut istihsan. ${ }^{16}$

Istihsan merupakan varian baru dari otorisasi qiyas sebagai metodologi hukum. Istihsan seringkali berbeda bahkan bertentangan dengan persepsi hukum Islam yang secara aksiomatik dapat diterima oleh pada umumnya ulama'. Penggunaan istihsan membutuhkan keberanian penggunaan nalar dalam memeberikan suatu putusan hukum. ${ }^{17}$ Pada awal istihsan, seringkali dianggap sebagai upaya penggunaan ra’yu (rasio) yang tidak memiliki rambu dan petunjuk yang sistematik. Dalam konteks ini, Abu Hanifah menyatakan bahwa istihsan bukanlah arbitrary opinion (pandangan yang subjektif dan illogical) melainkan sebuah prosedur atau metode yang jelas tentang bagaimana cara mengabaikan aturan-aturan yang ketat tentang qiyas dalam upaya mendapatkan keadilan dan kemashlahatan. Sebenarnya, masalah istihsan ini, sebelum masa Abu Hanifah, sudah ada dan masih belum menjadi kontroversi. Iyas b.Muawiyah (w. 122/740) sesungguhnya telah menggunakan istilah ini ketika memberikan intruksi : "gunakanlah qiyas dalam menetapkan keputusan selama itu bermanfaat bagi manusia, tetapi ketika ia akan memiliki implikasi yang kurang baik, maka gunakanlah istihsan (fastahsinu). Setelah Imam Abu Hanifah mengintroduksi ulang konsepnya, maka ragam

\footnotetext{
${ }^{16}$ Abdul Wahhab Khalaf, Ilmu ushul fikih- kaidah hukum Islam, terj. Faiz el muttaqin, 104.

${ }^{17}$ Nabil Shehaby, "illa and Qiyas in Early Islamic Legal Theory", Journal of the American Oriental Society, Vol. 102, No. 1 (Januari-Maret, 1982), 27-46.
} 
kontroversi mulai berkembang, tepatnya ketika dia mendefinisikan istihsan sebagai “ sesuatu yang sesuai dengan kemaslahatan manusia". ${ }^{18}$

Yang cukup menjadi bahasan krusial dan menjadi perdebatan panjang para ussuliyin berikutnya adalah tentang qiyas dan istihsan sebagaimana disinggung di atas, sebagai wujud "perseteruan teoretis" anatar madzhab shafi'I dan madhab Hanafi. Bagi al-syarakhsyi, metode istihsan, menggunakan akal dalam menemukan mashlahat dan keadilan itu lebih diutamakan daripada menggunakan qiyas, yakni pendapat madzabnya yang diyakini kuat dan benar. Baginya, mereka yang menolak metode ini adalah mereka yang tidak sepenuhnya paham akan makna dan maksut yang sesungguhnya. ${ }^{19}$

Kritik yang banyak dikemukakan adalah bahwa mereka yang menggunakan istihsan, sesungguhnya telah meninggalkan penggunaan qiyas yang sudah jelas menjadi argumentasi atau hujjah syar'iyah, seraya menyangka bahwa mereka telah mencari yang lebih baik. Bagaimana mereka akan mendapatkan yang terbaik sementara telah meninggalkan yang menjadi argumentasi dan mengkuti yang bukan argumentasi demi mengikuti hawa nafsunya? Jelaslah yang mere dapatkan adalah kesesatan belaka. ${ }^{20}$ Menanggapi tuduhan ini al-syarakhsi melakukan counter balance dengan mengemukakan argumentasi bahwa istihsan secara etimologis adalah eksistensi suatu yang baik, sehingga jika dikatakan saya ber-istihsan berarti saya yakin hal itu baik sebagai antithesis dari sesuatu yang jelek. Ini juga bermakna mencari yang lebih baik karena mengikuti perintah Allah : Fa bashbir 'ibadiyah al-ladhina yastami'un al-qawl fa yattabi'una ahsanahu, hal ini dimungkinkan dengan penggunaan logika. Dengan pertimbangan yang lebih kuat dan lebih baik, maka qiyas itulah yang dipakai. Ketika ada yang lebih kuat dan lebih baik, maka qiyas perlu ditinggalkan untuk masuk pada istihsan yang lebih merepresentasikan kemashlahatan yang memang menjadi tujuan utama shari'ah.

Al-Sarakhsi kemudian menyimpulkan bahwa sesungguhnya meninggalkan qiyas itu tidak selalu secara eksplisit meninggalkan nass. Kadangkala meninggalkan qiyas itu

\footnotetext{
18 Ahmad Imam Mawardi, Qiyas dan Istihsan-Dalam Rasionalitas Ushul Al-Sarakhsi, Islamica, IAIN Sunan Ampel Surabaya, Volume 7, Nomor 1, September 2012.

${ }^{19}$ Ahmad Imam Mawardi, Qiyas dan Istihsan-Dalam Rasionalitas Ushul Al-Sarakhsi, Islamica, IAIN Sunan Ampel Surabaya, Volume 7, Nomor 1, September 2012.

${ }^{20}$ Abu Bakr b. Ahmad b. Abi Sahl al-Sarakhsi, Usul al-Saraksi, Vol.2 (Beirut: Dar al-Kutub al-Ilmiyah, 1993), 118-119.
} 
didasarkan kepada nass, ijma' kadang kala didasarkan kondisi darurat. Contoh yang didasarkan pada nass adalah pendapat abu hanifah tentang perlunya qada' puasa bagi orang yang lupa makan ketika puasa. Dia mengatakan, andaikan aku tidak khawatir dengan apa yang dikatakan manusia, maka aku akan menyatakan bahwa puasanya wajib diganti”. Sebagai contoh adalah akad salam (titipan). Menurut qiyas hal ini tidak diperbolehkan karena tiadanya barang pada saat akad itu terjadi. Akan tetapi qiyas semacam ini ditinggalkan dengan dasar ada hadits nabi yang mengizinkan akad salam ini.

Contoh lainnya yang sangat menarik sebagai penegasan kepada mereka yang menganggap bahwa istihsan itu adalah sama dengan takhsis al-'illah adalah sebagai berikut. Sisa makanan atau air yang diminum oleh beruang liar adalah najis dan dilarang untuk dikonsumsi berdasarkan qiyas. Hal ini dianalogikan pada hadits yang menyatakan kenajisan binatang liar (bukan peliharaan). Analogi semacam ini ditolak dan digantikan dengan istihsan yang membolehkan hal tersebut di atas, dengan dasar logika bahwa sesungguhnya tidak ada larangan memanfaatkan binatang buas, dan ini menjadi indikasi bahwa esensinya adalah tidak najis. ${ }^{21}$

Kenajisannya adalah pada sisi keharaman untuk dimakan, kedua, binatang buas itu kalau makan langsung dengan menyentuh lidahnya pada makanan atau air yang ada, sementara burung tidak demikian, melainkan menggunakan paruhnya yang notabene adalah tulang. Sementara itu berdasarkan hadits, tulang dihukumi suci, karena itu, bekas makanan burung juga boleh untuk dikonsumsi. Istihsan juga mempunyai klasifikasi yakni istihsan menggunakan nass berarti anggapan baik serta dilandasi dengan nas yang ada, Ijma tidak bisa ditularkan pada kasus yang lain, dan Qiyas khafi bagian dari qiyas syari sehingga ia bisa diterapkan pada qiyas khafi pada kasus lain. Perbedaannya hukum ada kalanya diterapkan pada kasus yang lain / penerapan hukum kasus lain. Dikategori kan 2 unsur yakni istihsan yang menggunakan nass dan ijma' yang kedua yakni qiyas khafi.

Pada akhir bahasannya, al-syarakhsi memberikan uraian tentang fleksibelitas pandangannya tentang istihsan ini. Dia menyatakan bahwa apabila qiyas itu didukung oleh banyak nass yang kuat, maka ia tidak berkeberatan untuk berpihak pada qiyas dan

\footnotetext{
${ }^{21}$ Abdul Wahhab Khalaf, Ilmu ushul fikih- kaidah hukum Islam, terj. Faiz el muttaqin, 105.
} 
tidak menggunakan istihsan. Dan juga dalam penggunaanya lebih pada dua hal yakni pertama menggabungkan qiyas dan meninggalkan istihsan, yang kedua istihsan adalah yang dijadikan pedoman dan meninggalkan qiyas.

\section{TES URIN BAGI PASANGAN CALON PENGANTIN PERSPEKTIF ISTIHSAN $A L$ - $S Y A R A K H S Y$}

Perkembangan dibidang medis dikarenakan oleh kemajuan teknologi yang telah canggih pada era modern ini. Salah satunya yakni tes urin, yang merupakan kemajuan teknologi dibidang medis. Tes urin biasa digunakan untk mendeteksi kondisi kesehatan pada seseorang, seperti pendeteksi penyakit yang ada pada tubuh, salah satunya yakni sebagai pendeteksi adanya indikasi penggunaan narkoba atau tidak. Tes urine dalam bidang kedokteran biasa dilakukan di rumah sakit atau puskesmas oleh tenaga medis yang ahli dalam tes laboratorium, akan tetapi dalam kebijakan ini tes urine dilakukan di BNN terdekat secara gratis dan tidak dipungut biaya apapun. Pemanfaatan tes urine tidak hanya dalam bidang kesehatan saja, namun, seiring berkembangnya zaman dan semakin kompleksnya permasalahan yang dihadapi masyarakat, pemanfaatan tes urine bisa juga ikut berkembang dalam bidang lain, salah satunya dalam bidang hukum perkawinan. $^{22}$

Apabila ditinjau dari segi psikologis, sebenarnya tes urine pranikah dapat membantu menyiapkan mental pasangan. Sedangkan dari segi medis, sebagai usaha yang dapat membantu mencegah hal-hal yang tidak diinginkan di kemudian hari, sehingga dapat menjadi langkah antisipatif dan tindakan preventif yang dilakukan jauh-jauh hari untuk menghindarkan diri dari penyesalan dan penderitaan rumah tangga. Sekalipun tidak ada indikasi penyakit ataupun kelainan keturunan di dalam keluarga, berdasarkan prinsip syariah tetap dianjurkan untuk dilakukan pemeriksaan standar termasuk meliputi tes urine. Hal itu karena prinsip sentral syariah Islam adalah hikmah dan kemaslahatan umat manusia di dunia dan di akhirat. Tujuan utama ketentuan syariat (maqasid alsyariah) adalah tercermin dalam pemeliharaan pilar-pilar kesejahteraan umat manusia yang mencakup panca maslahat dengan memberikan perlindungan terhadap aspek keimanan (hifz aldin), kehidupan (hifz al-nafs), akal (hifz al-‘aql), keturunan (hifz al-

\footnotetext{
22 Tatimul Khalidah : Analisis Hukum Islam terhadap Kewajiban Tes Urine, AL-HUKAMA The Indonesian Journal of Islamic Family Law Volume 02, Nomor 01, Juni 2012.
} 
nasl) dan harta benda mereka (hifz almal). Apa saja yang menjamin terlindunginya lima perkara ini adalah maslahat bagi manusia dan dikehendaki syariah. ${ }^{23}$

Sedangkan segala yang membahayakannya dikategorikan sebagai mudarat atau mafsadat yang sebisa mungkin harus dihilangkan. Bahkan para ahli obstetri (ilmu kebidanan) dan ginekologi (ilmu keturunan) menyatakan bahwa sebaiknya calon pengantin memeriksakan dirinya tiga bulan sebelum melangsungkan perkawinan. Rentang waktu itu diperlukan untuk melakukan pengobatan jika ternyata salah seorang atau keduanya menderita gangguan tertentu. Jenis pemeriksaan kesehatan pranikah dapat disesuaikan dengan gejala tertentu yang dialami calon pengantin. Misalnya,pemeriksaan harus dilakukan lebih spesifik jika dalam keluarga didapati riwayat kesehatan yang kurang baik. Namun, jika semuanya lancar-lancar saja, maka hanya dilakukan pemeriksaan standar, yaitu cek darah dan tes urine. ${ }^{24}$

Dengan demikian, berdasarkan urgensi dan manfaat dari pemeriksaan kesehatan tersebut, syariat Islam sangat menyambut anjuran agar calon pengantin melakukan pemeriksaan kesehatan pranikah, yang diantaranya bisa meliputi pemeriksaan fertilitas dan tes kesehatan fisik, termasuk tes urine agar dapat diketahui lebih awal berbagai kendala dan kesulitan medis yang mungkin terjadi untuk diambil tindakan antisipatif. Selain itu sebagai upaya untuk menghindari penyesalan yang terjadi di kemudian hari pada diri masing-masing suami istri yang dapat memicu kehancuran rumah tangga. Hal ini berdasarkan prinsip sadd al-zari'ah (prinsip pengambilan langkah preventif terhadap segala hal yang dapat membahayakan bagi panca maslahat tersebut di atas).

Istihsan merupakan menganggap sesuatu itu baik. Maka dari itu adanya kebijakan kanwil kemenag dengan menambahkan tes urin bagi calon pengantin merupakan kebijakan yang dianggap baik, hal ini jelas bahwa kebijakan tersebut merupakan bentuk dari istihsan. Diangggap baik karna adanya kebijakan tersebut akan berdampak pada kemaslahatan keluarga kedepan. Pada hakikatnya istihsan bukanlah sumber hukum yang berdiri sendiri, karena dalil hukum dari bentuk istihsan pertama adalah qiyas yang tersembunyi yang diunggulkan dari pada yang nyata, sebab hal tertentu yang oleh mujtahid dianggap lebih unggul, dan itu adalah alasan istihsan.

\footnotetext{
${ }^{23}$ Abdul Wahhab Khalaf, Ilmu ushul fikih- kaidah hukum Islam, ... 97.

24 file:///E:/263-Article\%20Text-255-1-10-20170417.pdf, diakses pada 11 November 2019.
} 
Sedangkan dalil hukum dari bentuk istihsan yang kedua adalah kemaslahatan, yang menuntut adanya perkecualian bagian tertentu dari hukum umum, dan hal itu juga dianggap sebagai alasan istihsan.

Dengan kata lain kebijakan Diantara orang-orang yang berhujjah dengan istihsan adalah mayoritas kelompok hanafi. Mereka beralasan: pengambilan dalil dengan qiyas yang samar yang mengalahkan qiyas yang nyata, atau memenangkan qiyas atas qiyas lain yang menentangnya karna kepentingan umum dengan cara mengecualikan sebagian dari hukum umum. Dan semua itu adalah pengambilan dalil yang benar. Pada hal ini memakai istihsan al-sharakhsy yang mengemukakan bahwa metode istihsan yakni menggunakan akal dalam menentukan mashlahat dan keadilan itu lebih baik diutamakan daripada menggunakan qiyas adalah pendapat madhabnya yang diyakini kuat dan benar. Dilihat dari segi maslahat dan keadilan pada tes urine, sangat jelas bahwa tes urine akan berdampak pada kesejahteraan dari masyarakat sendiri yang mana harus dimulai dari keluarga. Karna dalam penyalahgunaan narkotika menjadi masalah besar yakni dapat menimbulkan ketergantungan yang berkepanjangan jika dipergunakan tidak sesuai dengan dosis dan pengawasan yang ketat. Penyalahgunaan narkotika juga mengakibatkan gangguan fisik, mental, sosial, keamanan dan ketertiban masyarakat.

Berdasarkan pemaparan di awal bahwa jika melihat urgensitas pemeriksaan kesehatan pranikah termasuk tes urine bagi calon pengantin, maka dapat dikatakan bahwa tes urine bagi calon pengantin hukumnya boleh atau mubah, karena mengacu pada teori maslahah dan hikmah altasyri', serta tidak ada nas yang melarang. Definisi mubah adalah sesuatu yang oleh syari' seorang mukallaf diperintahkan untuk memilih antara melakukan atau meninggalkan sesuatu tersebut. Kadang-kadang kebolehan berbuat itu ditetapkan dengan nass syara', seperti jika syari' menetapkan bahwa tidak berdosa berbuat ini, maka hal ini menunjukkan kebolehan. Suatu perbuatan yang pada awalnya dihukumi mubah bisa berubah menjadi sunah, makruh, wajib, bahkan haram. Seperti dalam masalah perkawinan, hukum asalnya adalah mubah, namun karena suatu hal maka bisa berubah menjadi wajib jika seseorang tersebut sudah mampu untuk menikah dan jika tidak menikah, dia sangat dikhawatirkan akan berbuat zina. Salah satu hikmah altasyri' perkawinan adalah menghalangi mata dari melihat hal-hal yang tidak diperbolehkan syara' dan menjaga kehormatan diri dari terjatuh pada kerusakan seksual. 
Oleh karena itu, bagi seseorang yang sudah mampu untuk menikah baik dari segi materi maupun immateri, disunahkan untuk segera menikah, agar terhindar dari perbuatan yang dilarang agama seperti zina. ${ }^{25}$

Dilihat dari macam-macamnya istihsan al-syarakhsy itu ada 2 yakni mengunggulkan kias yang tersembunyi atas kias yang nyata dengan suatu dalil dan mengecualikan sebagian hukum umum dengan suatu dalil. Dalam hal ini asal syarat dan rukun suatu pernikahan meliputi calon suami, calon istri, wali, dua orang saksi, dan ijab qobul, jika adanya penambahan syarat dalam pernikahan sebuah tes urin maka boleh atau sah menurut istihsan. Alasan istihsan yakni dalam hukum umumnya sebuah syarat pernikahan meliputi calon suami, calon istri, dua orang saksi dan lainya, akan tetapi adanya penambahan syarat bagi calon pengantin berupa tes urin yang tidak bertentangan dengan syara' dan dapat memberikan maslahat bagi kedua calon pengantin nanntinya. Jika calon pengantin melaksanakan tes urine maka dapat dipastikan generasi yang dilahirkan oleh setiap keluarga akan terjamin dari sisi jasmani maupun rohaninya. Karna jikalau seseorang terindikasi memakai narkoba maka ia akan menjalani rehabilitasi dahulu sebelum menjalani rumah tangga. Jika dilihat dari manfaat rehabilitasi itu salah satunya yakni dapat menyelamatkan hidup, artinya narkoba bisa memicu penyakit seperti HIV/AIDS, hepatitis hingga kerusakan organ penting seperti otak, jantung hingga paru-paru, yang mana jika dibiarkan kondisi ini bisa berujung pada kematian. Dengan adanya tes urin bagi calon pasangan juga dapat memicu hidup menjadi lebih positif, artinya jika ada pasangan yang terindikasi narkoba maka lingkungan rehabilitasi yang positif dinilai bisa membantu membebaskan seseorang dari narkoba. lingkungan ini pun diharapkan dapat mendorong perubahan perilaku para pecandu narkoba. Dengan rehabilitasi juga diharapkan dapat menerapkan prinsip abstinentia atau putus obat total. Dimana seorang pecandu tidak boleh mengonsumsi narkoba. hal ini tercantum dalam tiga aturan utama yakni dilarang memakai narkoba, dilarang berhubungan sexual secara sembarangan dan dilarang berbuat kekerasan. Pembiasaan yang disertai dengan proses penyadaran diri dinilai bisa membuat seorang pecandu tidak lagi mengonsumsi narkoba setelah keluar dari pusat rehabilitasi.

\footnotetext{
${ }^{25}$ Tatimul Khalidah : Analisis Hukum Islam terhadap Kewajiban Tes Urine, AL-HUKAMA The Indonesian Journal of Islamic Family Law Volume 02, Nomor 01, Juni 2012
} 
Dengan adanya tes urin bagi pasangan calon pengantin berarti telah mengupayakan kesehatan keluarga lebih baik. Karna akan semakin banyak masyarakat yang ketahuan jika mengonsumsi narkoba, dengan begitu akan lebih muda BNN melakukan upaya rehabilitasi bagi pengguna narkoba yang mana akan memicu beragam penyakit, mulai dari HIV/AIDS, liver, ginjal, dan paru-paru. ${ }^{26}$ Namun, dipusat rehabilitasi pecandu akan diajarkan untuk hidup tertib, bersih, berolahraga, serta mengonsumsi makanan sehat. Secara medis mereka juga diharuskan untuk memeriksakan kesehatan di laboratorium atau dirumah sakit. Kesehatan secara mental dan spiritualnya juga akan diperhatikan. Mereka akan diajarkan mengendalikan emosi dan cara mengatasi stress. Dengan demikian pecandu akan lebih sehat. Adanya diterapkan tes urin bagi pasangan pengantin, maka dapat membantu untuk mensejahterakan anak bangsa melalui unit yang paling terkecil yakni keluarga. ${ }^{27}$

Hemat penulis kebijakan kanwil kemenag tersebut tidaklah meyalahi aturan. Sebab, pemberlakuan kebijakan tersebut adalah demi kemaslahatan bersama, yaitu meminimalisir pengguna narkoba yang semakin memprihatinkan di wilayah Jawa Timur, mencegah para remaja untuk tidak mengonsumsi narkoba, dan menghindari adanya perkawinan yang mengandung kemudharatan, yakni akan membahayakan tubuhnya terutama susunan syaraf pusat/otak sehingga bilamana disalah gunakan akan menyebabkan gangguan fisik, psikis/jiwa dan fungsi sosial, maka dengan tes urine tersebut akan diketahui. Selain hal tersebut di atas, dengan adanya kewajiban tes urine bagi calon pengantin, maka semakin memudahkan dan membuat yakin PPN dalam menyelenggarakan kesejahteraan keluarga, sebab kondisi calon pengantin sudah bisa diketahui kesiapan dan kesehatannya. Beragamnya asumsi masyarakat tentang kewajiban tes urine tersebut, tetap tidak mengurangi ketaatan pegawai KUA terhadap kebijakan yang dikeluarkan oleh kanwil kemenag Jawa Timur.

Jadi, meskipun pada dasarnya ada sebagian pihak yang merasa keberatan dengan kewajiban tes urine, namun sebagai masyarakat masih menjunjung tinggi norma-norma lokal yang berlaku. Mereka tetap mengindahkan kebijakan yang ditetapkan oleh kanwil

\footnotetext{
${ }^{26}$ https://lifestyle.sindonews.com-manfaat.rehabilitasi-bagi-pecandu-narkoba.diana-rafikasari diakses pada 11-November-2019.

${ }^{27}$ Tatimul Khalidah : Analisis Hukum Islam terhadap Kewajiban Tes Urine, AL-HUKAMA The Indonesian Journal of Islamic Family Law Volume 02, Nomor 01, Juni 2012
} 
kemenag Jawa Timur tersebut, sebab di satu sisi mereka juga ingin proses pendaftaran perkawinannya segera cepat selesai sehingga pelaksanaan perkawinan mereka berjalan lancar tanpa ada kendala dalam hal pencatatan perkawinan. Dari segi kemaslahatan, diwajibkannya tes urine bagi calon pengantin dapat mempertegas penegakan hukum Selain itu, dengan adanya tes urine akan menghindarkan kedua belah pihak dari unsur penipuan dalam perkawinan, sebab pasangan yang memakai narkoba akan terlihat setelah melakukan tes urine, sehingga tidak akan ada yang merasa dirugikan di kemudian hari karena sudah mengetahui sejak sebelum menikah. ${ }^{28}$

Meskipun tes urine mempunyai dampak positif, namun pada sebagian orang ada yang berpendapat bahwa tes urine dapat menambah pekerjaan atau bahkan memberikan pembebanan lebih terhadap calon pengantin, sebab dengan adanya kebijakan tersebut, maka mau tidak mau mengharuskan para calon pengantin untuk melakukan tes urine yang pada awalnya ketentuan tersebut tidak ada, dan yang paling krusial adalah adanya tambahan biaya dalam perkawinan jika tes urin dilaksanakan selain di BNN. Kewajiban tes urine yang diberlakukan di wilayah Jawa Timur ini sejalan dengan kaidah usuliyah "dar'u almafasid muqaddamun 'ala jalbi al-masalih" (menolak kemadaratan lebih diutamakan daripada menarik kemaslahatan), yang dalam hal ini kaitannya adalah mewajibkan tes urine bagi setiap calon pengantin untuk menghindari adanya perkwinan yang mengandung garar, yakni adanya aib yang ditutup-tutupi diantara suami istri.

\section{PENUTUP}

Bagi al-Syarakhsy metode Istihsan menggunakan akal dalam menemukan mashlahat dan keadilan itu diutamakan dari pada menggunakan qiyas. Artinya dalam hukum umumnya sebuah syarat pernikahan meliputi calon suami, calon istri, dua orang saksi dan lainya, akan tetapi adanya penambahan syarat bagi calon pengantin berupa tes urin yang tidak bertentangan dengan syara' dan dapat memberikan maslahat bagi kedua calon pengantin nanntinya. Jika calon pengantin melaksanakan tes urine maka dapat dipastikan generasi yang dilahirkan oleh setiap keluarga akan terjamin dari sisi jasmani maupun rohaninya. Karna jikalau seseorang terindikasi memakai narkoba maka ia akan menjalani rehabilitasi dahulu sebelum menjalani rumah tangga. Jika dilihat dari manfaat

\footnotetext{
${ }^{28}$ Tatimul Khalidah : Analisis Hukum Islam terhadap Kewajiban Tes Urine, AL-HUKAMA The Indonesian Journal of Islamic Family Law Volume 02, Nomor 01, Juni 2012
} 
rehabilitasi itu salah satunya yakni dapat menyelamatkan hidup, artinya narkoba bisa memicu penyakit seperti HIV/AIDS, hepatitis hingga kerusakan organ penting seperti otak, jantung hingga paru-paru, yang mana jika dibiarkan kondisi ini bisa berujung pada kematian. Dengan adanya tes urin bagi calon pasangan juga dapat memicu hidup menjadi lebih positif, artinya jika ada pasangan yang terindikasi narkoba maka lingkungan rehabilitasi yang positif dinilai bisa membantu membebaskan seseorang dari narkoba. lingkungan ini pun diharapkan dapat mendorong perubahan perilaku para pecandu narkoba.

\section{DAFTAR PUSTAKA}

A. Masjkur Anhari, 2007, Usaha-Usaha untuk Memberikan Kepastian Hukum dalam Perkawinan, Surabaya: Diantama.

Abd. Rahman Ghazaly, 2006, Fiqh Munakahat, Cet. II, Jakarta: Kencana.

Abdul Wahhab Khalaf, 2003, Ilmu ushul fikih- kaidah hukum Islam, terj. Faiz el muttaqin, Jakarta: pustaka amani.

Abdul Wahhab Khalaf, Ilmu ushul fikih- kaidah hukum Islam, terj. Faiz el muttaqin.

Abu Bakr b. Ahmad b. Abi Sahl al-Sarakhsi, 1993, Usul al-Saraksi, Vol.2 Beirut: Dar alKutub al-Ilmiyah.

Abu Malik kamal bin Sayyid Salim, 2007, Fiqh Sunnah untuk Wanita, Jakarta: AlI'tishom Cahaya Umat.

Ahmad Imam Mawardi, Qiyas dan Istihsan-Dalam Rasionalitas Ushul Al-Sarakhsi, Islamica, IAIN Sunan Ampel Surabaya, Volume 7, Nomor 1, September 2012. Ahmad Rofiq, 1997, Hukum Islam di Indonesia, cet. II Jakarta: Rajawali Press. Andi Hamzah, 1991, Perkembangan Hukum Pidana Khusus, Jakarta: Rineka Cipta. file://E:/263-Article\%20Text-255-1-10-20170417.pdf, diakses pada 11 November 2019.

https://lifestyle.sindonews.com-manfaat.rehabilitasi-bagi-pecandu-narkoba.dianarafikasari diakses pada 11-November-2019. https://m.cnnindonesia.com/nasional/20190713020347-20-411767/kua-di-jatim-bakalwajibkan-calon-pengantin-tes-urine diakses pada 05 November 2019. 
https://surabaya.liputan6.com/read/4017888/calon-pengantin-di-surabaya-wajib-tes-

urine-mulai-agustus-2019-mengapa diakses pada 06 November 2019.

Kompilasi Hukum Islam (KHI) Cet. Terbaru: Permata Press.

Nabil Shehaby, 1982, "illa and Qiyas in Early Islamic Legal Theory”, Journal of the American Oriental Society, Vol. 102, No. 1 Januari-Maret.

Sa'id bin Abdullah bin Thalib al Hamdani, 2002, Risalah al-Nikah, terjemahan, Agus Salim, Risalah Nikah; Hukum Perkawinan Islam, Jakarta: Pustaka Amani.

Tatimul Khalidah : Analisis Hukum Islam terhadap Kewajiban Tes Urine, ALHUKAMA The Indonesian Journal of Islamic Family Law Volume 02, Nomor 01, Juni 2012.

Taufik Makarao, dkk, 2003, Tindak Pidana Narkotika, Jakarta: Ghalia Indonesia.

Wasman, Wardah Nuroniyah, 2011, Hukum Perkawinan Islam di Indonesia; Perbandingan Fiqh dan Hukum Positif, Cet. 1, Yogyakarta: Teras. 